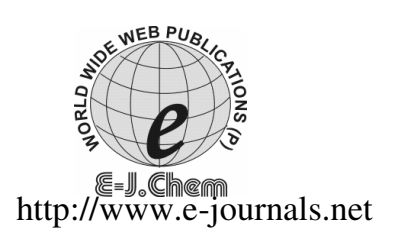

ISSN: 0973-4945; CODEN ECJHAO

E-Journal of Chemistry

2010, 7(4), 1174-1183

\title{
Accumulation of Lead and Cadmium in Soil and Vegetable Crops along Major Highways in Agra (India)
}

\author{
SHASHANK SHARMA* and F.M.PRASAD \\ Department of Chemistry \\ School of Chemical Sciences, St. John's College, Agra- 282002, India. \\ shashanktkd@yahoo.com
}

Received 23 August 2009; Revised 10 January 2010; Accepted 5 March 2010

\begin{abstract}
Environmental pollution of heavy metals from automobiles has attained much attention in the recent past. The present research was conducted to study $\mathrm{Pb}$ and $\mathrm{Cd}$ level concentrations in soil and vegetations along a major highway with high traffic density. Soil and vegetable samples along highway were collected from 10 sites in Agra district (India) and analyzed for two heavy metals (lead and cadmium) using flame atomic absorption spectrophotometer (AAS). The soil physicochemical properties were also determined. The general decrease in concentrations of these metals with distance from the highway indicates their relation to traffic. Higher accumulations of metals have been observed on vegetation and soil samples near to the highway $(0-5 \mathrm{~m})$ than on vegetation and soil samples from sites a little farther away ( at 5-10 m \& 10-15 m). This is attributed mainly to aerial deposition of the metal particulates from motor vehicles. The values of heavy metals were compared with results found by other investigators in various countries worldwide.
\end{abstract}

Keywords: Environmental pollution, Heavy metals, AAS, Traffic density.

\section{Introduction}

The pollution of soils by heavy metals from automobile sources is a serious environmental issue. Results show that roadside soil near motorways is heavily polluted by heavy metals from automobiles ${ }^{1,2}$. These metals are released during different operations of road transport such as combustion, component wear, fluid leakage and corrosion of metals. Lead and cadmium are the major metal pollutants of the roadside environments and are released from fuel burning; wear out of tires, leakage of oils etc $^{3}$.

The elevated levels of $\mathrm{Pb}$ and $\mathrm{Cd}$ in urban areas are mainly attributed to automobile exhaust, particularly from leaded gasoline, motor vehicle tires, and lubricant oils ${ }^{4-6}$. Recently it was claimed that $\mathrm{Pb}$ in urban areas could be over $1000 \mathrm{ppm}$, where as tolerable intake of ingested $\mathrm{Pb}$ for adults is $3000 \mu \mathrm{g}$ per week, which is equivalent to an average daily uptake of $430 \mu \mathrm{g}$ and $130 \mu \mathrm{g}$ for children ${ }^{7}$. For $\mathrm{Cd}$, critical levels for adults, food source and water are 
120, 45 and $13 \mu \mathrm{g}$ per day respectively. In addition, FAO/WHO recommended maximum tolerable intake of $\mathrm{Cd}$ of $400-500 \mu \mathrm{g}$ per week or equal $70 \mu \mathrm{g}$ per day. Several studies revealed that $60-80 \%$ of heavy metal toxins found in human bodies in urban areas were the results of consuming contaminated foods rather than air pollution ${ }^{8-11}$.

A great part of metal pollutants are deposited on adjacent soil where they may be transformed and transported to other parts of the environment for example, to vegetation. In addition to soil, vegetables function as a sink for atmospheric pollutants because of its capacity to act as efficient interceptions of airborne matter. The plants are widely used as passive bio-monitors in urban environments ${ }^{12,13}$.There is no doubt that leafy vegetables grown in the neighborhood of major motorways, can contain significant traces of $\mathrm{Pb}$ and $\mathrm{Cd}$ due to airborne metal particulates derived from motor vehicle emissions. The distribution of these metals $(\mathrm{Pb}$ and $\mathrm{Cd})$ in the roadside soils is strongly but inversely correlated with the distances away from the roadside ${ }^{14,15}$.

The tremendous increase in the number of motor vehicles in Agra city is leading to increasingly high levels of some heavy metals in the urban as well as highway environment ${ }^{16}$. This work consists of study of the distribution of $\mathrm{Pb}$ and $\mathrm{Cd}$ in surface soil $(0-15 \mathrm{~cm})$ and in leaves of some vegetable crops sampled at distances from the center of traffic flow along a highway.

\section{Experimental}

Agra is one of the most famous tourist spots of the country. The city, situated on the west bank of river Yamuna, is known world over as home to a wonder of the world, Taj Mahal. A part of the great Northern Indian plains, Agra has a tropical climate. The climate during summer is hot and dry with temperature ranging from $32{ }^{\circ} \mathrm{C}$ to $48{ }^{\circ} \mathrm{C}$. In winter the temperature ranges from $3.5{ }^{\circ} \mathrm{C}$ to $30.5{ }^{\circ} \mathrm{C}$. The downward wind is South-South-East i.e. SSE $29 \%$ and North-East i.e. NE $6 \%$ in summers and it is West-North-West i.e. WNW $9.4 \%$ and North-North-West i.e. $11.8 \%$ in winters. Agra, the city of Taj, $\left(27^{\circ} 10^{\prime} \mathrm{N} 78^{\circ} 02^{\prime} \mathrm{E}\right)$ is located in the north central part of India. It is considered as a semi-arid zone as two third of its peripheral boundaries are surrounded by the Thar Desert of Rajasthan. The atmospheric pollution load is high \& because of the down ward wind, pollutant may be transported to the different areas Agra has about 1316177 total populations and population density is about 21148 per sq km with 386635 vehicles registered $^{16}$. Vehicular exhaust accounts for more than $50 \%$ of the total pollution from all the sources put together in all big cities of India ${ }^{17}$. In Agra, $60 \%$ pollution is due to vehicles ${ }^{18}$.

\section{Collection of samples}

Samples were collected from the Mathura- Kanpur highway about $15 \mathrm{~km}$ from the nearest urban center (Agra city). This highway carrying an average of $10^{5}$ motor vehicles per day. 10 Sites were selected for the study along this highway. At each site, three samples of soils and three samples of vegetables were collected at different distance from the edge of the main road $(0-5 \mathrm{~m}, 5-10 \mathrm{~m}, 10-15 \mathrm{~m})$. The sites were particularly suitable because: (i) the traffic density is comparatively very high; (ii) there are no urban, large scale urban or industrial activities; (iii) there are no major road intersections which can cause a significant decrease in traffic density to and from Agra city.

\section{Sample preparation and analysis}

Soil samples were air-dried, ground in a porcelain mortar to pass through a $2 \mathrm{~mm}$ sieve. About $1 \mathrm{~g}$ of soil was accurately weighed and transformed to a $100 \mathrm{~mL}$ conical flask and $5 \mathrm{~mL}$ of conc. $\mathrm{HNO}_{3}(\mathrm{AR} 70 \%$ ) was added and kept it for overnight. The flask was placed on a hot plate inside a fume hood, heated at a temperature of $70^{\circ} \mathrm{C}$ for $1 \mathrm{~h}$, and then kept it for 
cooling for $30 \mathrm{~min}$ and $5 \mathrm{~mL}$ of aquaregia, a mixture of conc. $\mathrm{HNO}_{3}$ and $\mathrm{HClO}_{4}(\mathrm{AR} 70 \%$, Merck) in a ratio of 4:1 was added and again the flask was placed on hot plate, heated at a temperature of $80{ }^{\circ} \mathrm{C}$ for $2 \mathrm{~h}$. After that it was cooled for $1 \mathrm{~h}$ and transferred to $100 \mathrm{~mL}$ volumetric flask through filtration (Whatmann 42) and the final volume was made up to the mark with double distilled water, mixed well by shaking, and let settle for at $15 \mathrm{~h}$. The resultant supernatant was analyzed by flame atomic absorption spectrophotometer (FAAS, Perkin -Elmer, ANALYST 100) for total Pb and $\mathrm{Cd}$. The instrument was calibrated using $\mathrm{Pb}$ and $\mathrm{Cd}$ standard for each element being analyzed. Laboratory blanks were prepared by adding $10 \%$ aquaregia to a conical flask containing none of the sample being investigated. This consisted of all components added to the matrix during digestion. All soil and blank samples were analyzed for total trace metal levels.

Leaves of vegetables from different sites have been collected by hand, carefully packed in to polythene bags and brought to the laboratory for the further analysis. These leaves were carefully washed with tap water to eliminate the adhering soil and other contaminates. Plant samples were oven dried at $100{ }^{\circ} \mathrm{C}$ for $48 \mathrm{~h}$, ground in a porcelain mortar to pass a $2 \mathrm{~mm}$ sieve. 1 $\mathrm{g}$ of ground-dried sample were taken and placed it in a small beaker. $10 \mathrm{~mL}$ of concentrated $\mathrm{HNO}_{3}$ was added and allowed it to stand overnight. Then it was carefully heated on a hot plate until the production of red $\mathrm{NO}_{2}$ fumes has ceased. It was kept for cooling and a small amount (2$4 \mathrm{~mL}$ ) of $70 \% \mathrm{HClO}_{4}$ was added. Heated again and allowed to operate a small volume. The sample was transferred to a $50 \mathrm{~mL}$ flask and made up with double distilled water. Then the quantification of metallic content $(\mathrm{Pb} \& \mathrm{Cd})$ of digested samples was carried out with the FAAS.

\section{Statistical analysis}

One - way analysis of variance (ANOVA) was applied to find out the correlation of metal (total) concentrations in the soils and vegetables with the distances from roadside. In addition, Pearson's correlation was used to evaluate the metal concentration in soil and vegetable versus distance from road with the help of software SIGMA STAT 3.5.

\section{Results and Discussion}

The physicochemical properties of soil at roadside agricultural sites in Agra are presented in Table 1. Maximum $\mathrm{pH}$ of the roadside soil was found to be 9.20 at site 4 (mean value) and minimum $\mathrm{pH}$ was observed 7.44 at site 6 (mean value). The maximum electric conductance value for roadside soil was $0.88 \mathrm{ds} / \mathrm{m}$ at site 4 , which is approximately five times higher than the minimum EC mean value at site $10(0.16 \mathrm{ds} / \mathrm{m})$. The max mean value of organic carbon $(\%)$ was found at site $2(1.59 \%)$ while minimum mean value of organic carbon in roadside soil was $0.38 \%$ at site 5 .

Table 1. Physicochemical properties of soils in roadside soils. (Mean values)

\begin{tabular}{cccc}
\hline Site & $\mathrm{pH}$ & $\mathrm{EC}(\mathrm{ds} / \mathrm{m})$ & $\mathrm{OC}, \%$ \\
\hline 1 & 8.65 & 0.65 & 0.53 \\
2 & 8.66 & 0.44 & 1.53 \\
3 & 8.55 & 0.49 & 0.73 \\
4 & 9.20 & 0.88 & 0.52 \\
5 & 8.09 & 0.18 & 0.24 \\
6 & 7.44 & 0.42 & 0.50 \\
7 & 8.35 & 0.18 & 0.38 \\
8 & 7.72 & 0.20 & 0.47 \\
9 & 7.98 & 0.41 & 0.37 \\
10 & 7.89 & 0.16 & 0.67 \\
\hline
\end{tabular}


In the present study, the distance from the road was served as a treatment. Therefore, heavy metals $(\mathrm{Pb} \& \mathrm{Cd})$ contents in soil as well as vegetables were measured in triplicates of three regions of each site (0-5 m, 5-10, 10-15 m). Three samples of soils and vegetables each were collected from particular region.

\section{Lead}

The amount of lead in roadside soil is strongly but inversely correlated with the increase in the distance from road ${ }^{19}$. Table 2 and Figure 1 show the lead content in roadside soil at different distance. At site 2, the lead concentration is highest $(50.10 \pm 1.94 \mathrm{mg} / \mathrm{kg})$ but it decreased with the increasing distance from roadside; $24.13 \pm 2.57(5-10 \mathrm{~m}) \& 14.90 \pm 3.34$ (at $10-15 \mathrm{~m})$. In the present study, the lead content of roadside soil ranged from 0.00 to $50.10 \mathrm{mg} / \mathrm{kg}$ (mean values). By considering the general range of the total lead content, it appears that the total lead content in $85 \%$ roadside soils was below the critical conc. of $400 \mathrm{mg} / \mathrm{kg}^{20}$. In the last decades much attention has been directed towards lead in the roadside environments as a result of its widespread use as an antiknocking agent in gasoline ${ }^{21-24}$. Due to growing concerns about the problems associated with $\mathrm{Pb}$, the use of leaded gasoline has been decreasing globally at an annual rate of about $7 \%{ }^{25}$. The maximum level of $\mathrm{Pb}$ in leaded gasoline has been set to be less than $0.15 \mathrm{~g} / \mathrm{L}$ since July $1989^{26}$, but there are still many counties that use of leaded gasoline with $\mathrm{Pb}$ content of about $0.4 \mathrm{~g} / \mathrm{L}^{25,27}$. Although the use leaded gasoline decreased during this time period, but the increasing number of automobile compensated its effect on the vehicles based on lead emission. In addition, wearing down of vehicle tires can also introduce $\mathrm{Pb}^{28}$ to the roadside soil. Consequently, road transport is still polluting the atmosphere, soil and water near the highway ${ }^{29-31}$.

Table 2. Lead $(\mathrm{mg} / \mathrm{kg})$ in roadside agricultural soil at selected sites

\begin{tabular}{cccc}
\hline \multirow{2}{*}{ Site } & $0-5 \mathrm{~m}$ & Distance from road $(\mathrm{m})$ & \\
& $12.60 \pm 0.81(11.70-13.30)$ & $10.13 \pm 0.25(9.90-10.40)$ & $9.40 \pm 0.98(8.30-10.20)$ \\
1 & $50.10 \pm 1.94(48.60-52.30)$ & $24.13 \pm 2.57(21.20-26.00)$ & $14.90 \pm 3.45(12.40-18.70)$ \\
3 & $11.80 \pm 0.98(11.00-12.90)$ & $10.73 \pm 0.23(10.60-11.00)$ & $4.63 \pm 0.83(4.10-5.60)$ \\
4 & $17.33 \pm 0.64(16.60-17.80)$ & $13.90 \pm 0.91(13.10-14.90)$ & $12.13 \pm 1.44(11.20-13.80)$ \\
5 & $19.50 \pm 1.25(18.20-20.70)$ & $3.20 \pm 0.43(2.90-3.70)$ & $0.00 \pm 0.00(0.00-0.00)$ \\
6 & $5.60 \pm 0.36(5.30-6.00)$ & $2.30 \pm 0.20(2.10-2.50)$ & $0.00 \pm 0.000 .00-0.00)$ \\
7 & $4.17 \pm 0.32(3.80-4.40)$ & $3.33 \pm 0.55(2.80-390)$ & $2.10 \pm 0.17(2.00-2.30)$ \\
8 & $15.13 \pm 1.49(13.90-16.80)$ & $12.40 \pm 0.78(11.50-12.90)$ & $2.90 \pm 0.85(2.00-3.70)$ \\
9 & $6.90 \pm 0.55(6.30-7.40)$ & $3.60 \pm 0.36(3.20-3.90)$ & $3.10 \pm 0.45(2.60-3.50)$ \\
10 & $6.13 \pm 0.15(6.00-6.30)$ & $2.73 \pm 0.58(2.30-3.40)$ & $4.60 \pm 0.60(3.90-5.00)$ \\
\hline & & $M e a n \pm S D($ Range &
\end{tabular}

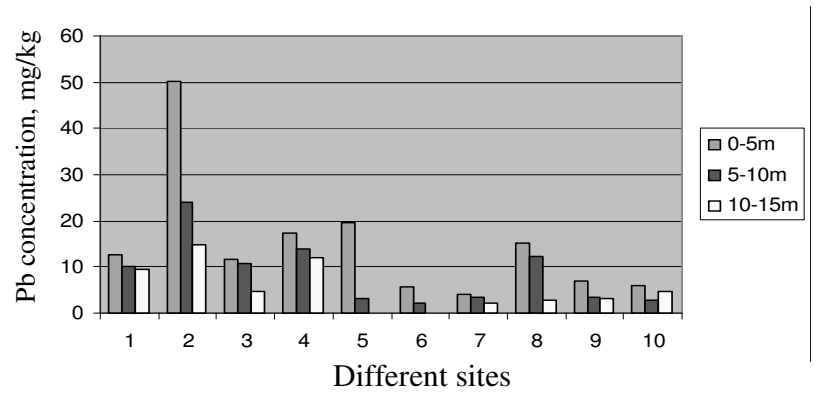

Figure 1. $\mathrm{Pb}(\mathrm{mg} / \mathrm{kg})$ in roadside agricultural soils 
In terms of distance from the main road, there were high correlations between $\mathrm{Pb}$ content and distance, these were from $r=-0.45, p>0.05$ (at site 10) to $r=-0.99, p<0.01$ (at site 6.). Highly significant correlation of $\mathrm{Pb}$ content in soil and distance were observed at all sites except of site $10(r=-0.45, p>0.05)$ It means that relationship between distance and average values of lead content was found to be inversely correlated at most of the sites. The mean values of $\mathrm{Pb}$ obtained from all the soil sampled at different distances away from the highway were significantly different $(\mathrm{p}<0.01)$. Pb content in soil was still within the acceptable limits as reported by Tsadilas (2000), where the range of $\mathrm{Pb}$ accumulated in uncontaminated soils reached $15-106 \mathrm{ug} / \mathrm{g}$ dry weight. In polluted soils, $\mathrm{Pb}$ content ranges limit from 100 to $400 \mathrm{ug} / \mathrm{g}$ dry weight. $\mathrm{Pb}$ content in soil near road was lower than EU upper limit of $300 \mathrm{mg} / \mathrm{kg}^{32}$ and was at $\mathrm{mg} / \mathrm{kg}^{33}$.

Lead, although not readily soluble in soil, is absorbed mainly by root hairs and is stored in the cell walls. The translocation of $\mathrm{Pb}$ from roots to tops is greatly limited ${ }^{34-36}$ and as Zimdahl (1976) described ${ }^{37}$; only $3 \%$ of the $\mathrm{Pb}$ in the root is translocated to the shoot. Lead mobility and bioavailability are controlled by several soil factors such as $\mathrm{pH}$, redox potential, organic matter and the chemical from and species of lead ${ }^{38}$. Airborne $\mathrm{Pb}$, a major source of $\mathrm{Pb}$ pollution, is also readily taken up by plants through foliage ${ }^{39}$. The epidermal cells absorb $\mathrm{Pb}$ deposited on the leaf surface.

Cauliflower, cabbage, Okra, radish, spinach and brinjal contained high mean concentration of $\mathrm{Pb}$ (Table 3 and Figure 2). The concentrations of $\mathrm{Pb}$ showed a decreasing trend as the distance increased from the road edge. At site 4 , the lead concentration in brinjal beside the roadside was found to be highest $(31.20 \pm 2.94 \mathrm{mg} / \mathrm{kg})$ but it is decreased with the

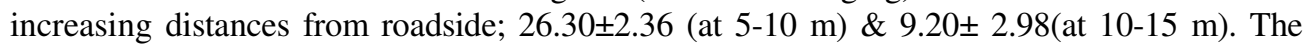
lowest lead concentration in radish near road was $1.5 \pm 0.1 \mathrm{mg} / \mathrm{kg}$ which is decreased to $1.20 \pm 0.30 \mathrm{mg} / \mathrm{kg}$ (at $5-10 \mathrm{~m}$ ) followed by $0.00 \pm 0.00 \mathrm{mg} / \mathrm{kg}$ (at $10-15 \mathrm{~m}$ ). Simple correlation analysis revealed negative correlations between $\mathrm{Pb}$ content and a distance, these were form $\mathrm{r}$ $=-0.77, \mathrm{p}<0.05$ (at site 2) to $\mathrm{r}=-0.99, \mathrm{p}<0.01$ (at site 1 ).

Table 3. Lead $(\mathrm{mg} / \mathrm{kg})$ in vegetable leaves at selected sites

\begin{tabular}{|c|c|c|c|c|}
\hline \multirow[t]{2}{*}{$\stackrel{\oplus}{=}$} & Vegetable & \multicolumn{3}{|c|}{ Distance from road $(\mathrm{m})$} \\
\hline & & $0-5 \mathrm{~m}$ & $5-10 \mathrm{~m}$ & $10-15 \mathrm{~m}$ \\
\hline 1 & Cauliflower & $10.20 \pm 0.95(9.10-10.80)$ & $6.93 \pm 0.30(6.60-7.20)$ & $3.40 \pm 1.17(2.40-4.70)$ \\
\hline 2 & Cabbage & $15.30 \pm 1.70(13.60-17.00)$ & $9.70 \pm 1.12(9.00-11.00)$ & $10.63 \pm 1.32(9.10-11.40$ \\
\hline 3 & Cauliflower & $9.70 \pm 0.60(9.00-10.10)$ & $7.40 \pm 0.45(6.90-7.80)$ & $7.33 \pm 0.64(6.60-7.80)$ \\
\hline 4 & Brinjal & $31.20 \pm 2.94(28.00-33.80)$ & $26.30 \pm 2.36(23.80-28.50)$ & $9.20 \pm 2.98(6.70-12.50)$ \\
\hline 5 & Brinjal & $14.40 \pm 0.52(13.80-14.80)$ & $8.70 \pm 1.21(7.60-10.00)$ & $8.30 \pm 1.25(7.00-9.50)$ \\
\hline 6 & Radish & $4.80 \pm 0.88(4.10-5.80)$ & $3.00 \pm 0.36(2.70-3.40)$ & $0.50 \pm 0.26(0.20-0.70)$ \\
\hline 7 & Spinach & $2.93 \pm 0.75(2.20-3.70)$ & $1.70 \pm 0.10(1.60-1.80)$ & $0.00 \pm 0.00(0.00-0.00)$ \\
\hline 8 & Spinach & $5.90 \pm 0.40(5.50-6.30)$ & $5.10 \pm 0.81(4.40-6.00)$ & $2.30 \pm 0.79(1.70-3.20)$ \\
\hline 9 & Okra & $1.70 \pm 0.26(1.50-2.00)$ & $1.10 \pm 0.30(0.80-1.40)$ & $0.70 \pm 0.10(0.60-0.80)$ \\
\hline 10 & Radish & $1.50 \pm 0.10(1.40-1.60)$ & $1.20 \pm 0.30(0.90-1.50)$ & $0.00 \pm 0.00(0.00-0.00)$ \\
\hline
\end{tabular}

Mean $\pm S D$ (Range)

The mean values of $\mathrm{Pb}$ obtained from all the vegetables samples at different distances away from the highway were significantly different $(\mathrm{p}<0.01)$. The $\mathrm{Pb}$ concentrations in all the leafy vegetable samples $(0-5 \mathrm{~m})$ except that of site $9 \&$ of site 10 , exceeded the Indian 
Prevention of Food Adulteration Act (PFA) permissible limit of $2.5 \mathrm{mg} / \mathrm{kg}$. But if the more stringent CODEX limit of $0.3 \mathrm{mg} / \mathrm{kg}$ is used, then $100 \%$ of vegetable leaves sample exceeded safe limits. Approximately 50\% of the samples exceeded the PFA permissible limit by more than 2 fold (i.e., had concentrations of $>5.0 \mathrm{mg} / \mathrm{kg}$ ).

Table 4. Cadmium $(\mathrm{mg} / \mathrm{kg})$ in roadside agricultural soil at selected sites

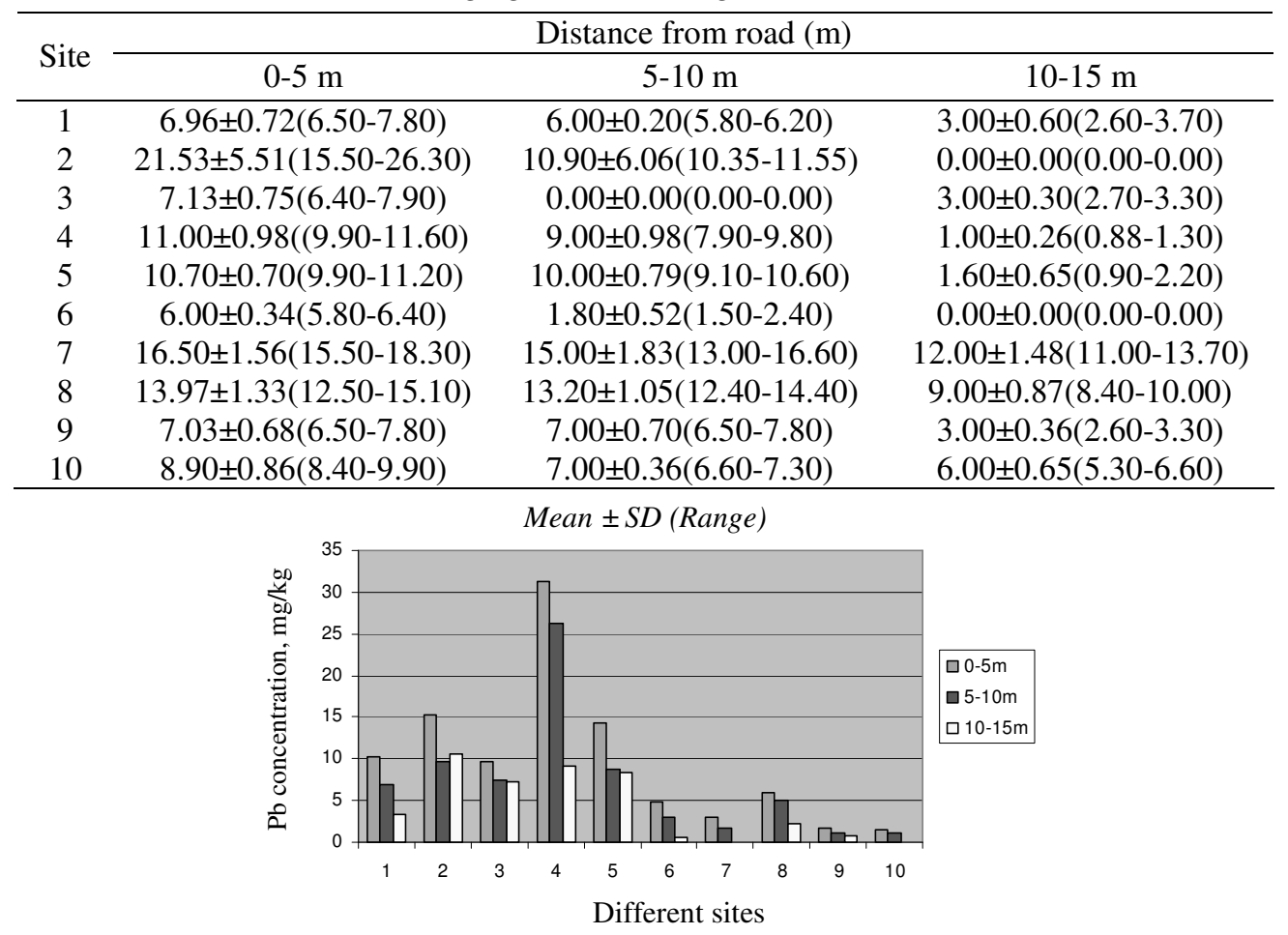

Figure 2. $\mathrm{Pb}(\mathrm{mg} / \mathrm{kg})$ in roadside vegetable leaves

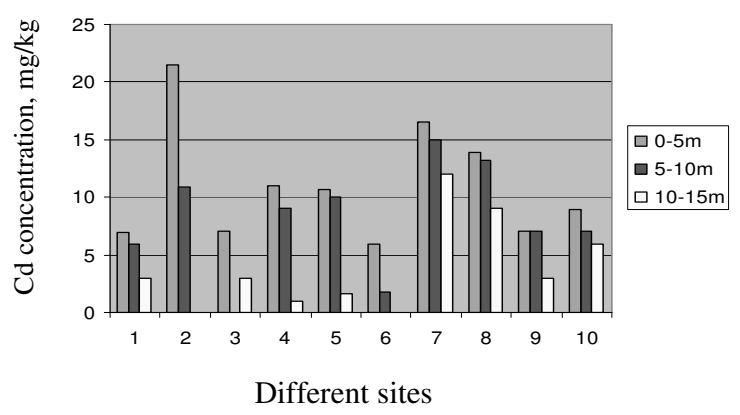

Figure 3. $\mathrm{Cd}(\mathrm{mg} / \mathrm{kg})$ in roadside agricultural soils

\section{Cadmium}

Cd levels in exhaust emissions have been related to the composition of gasoline, motor oil, car tires and roadside deposition of the residues of those materials as well as traffic density ${ }^{40}$. All the sites investigated had Cd above the recommended $1-3 \mathrm{mg} / \mathrm{kg}$ limit given by EU. 
(Table 4 \& Figure 3) Highest concentration of $\mathrm{Cd}$ in soil (site 2) at distance $0-5 \mathrm{~m}$ from road was $21.53 \mathrm{mg} / \mathrm{kg}$ which is decreased to (about $50 \%) 10.90 \mathrm{mg} / \mathrm{kg}(5-10 \mathrm{~m}) \& 0.00 \mathrm{mg} / \mathrm{kg}$ $(10-15 \mathrm{~m})$. The lowest concentration of $\mathrm{Cd}$ in soil (site 6) at distance 0-5 $\mathrm{m}$ from road was $6.00 \mathrm{mg} / \mathrm{kg}$ which is decreased to $1.80 \mathrm{mg} / \mathrm{kg}(30 \%)$ at distance $5-10 \mathrm{~m}$ and followed by $0.00 \mathrm{mg} / \mathrm{kg}$ at $10-15 \mathrm{~m}$ from road. However, the sources of $\mathrm{Cd}$ in the urban areas are much less well defined than those of $\mathrm{Pb}$, but metal plating and tire rubber were considered the likely sources of cadmium ${ }^{41}$. In the absence of any major industry in the sampling sites, the levels of cadmium could be due to lubricating oils and/or old tires that are frequently used and the rough surfaces of the roads, which increase the wearing of tires.

Correlation calculations performed on Cd concentrations in soil showed that significant negative correlation are present between $\mathrm{Cd}$ content and distance from road at all sites except at site $2 \&$ at site 3 . These were from $r=-0.18, p>0.05$ (at site 2 ) to $r=-0.98, p<$ 0.01 (at site 10). The mean values of $\mathrm{Cd}$ of all soil sampled at different distances away from the highway was significantly different $(\mathrm{p}<0.01) .0-1 \mathrm{mg} / \mathrm{kg}$ of $\mathrm{Cd}$ in soils indicates noncontamination, $1-3 \mathrm{mg} / \mathrm{kg}$ indicates slight contamination and $3-10 \mathrm{mg} / \mathrm{kg}$ indicates a contaminated soil ${ }^{43}$. At $0-5 \mathrm{~m}$ from road, all the soil samples contained more $\mathrm{Cd}$ than 3 $\mathrm{mg} / \mathrm{kg}$ and could be considered as contaminated.

It is well known that concentrations of $\mathrm{Cd}$ in edible vegetables range from 0.05 to $0.9 \mathrm{mg} / \mathrm{kg}$ (dry weight) and leafy plants such as cabbage, spinach contains relatively higher $\mathrm{Cd}$ than grain or fruit plant such as apple and barley ${ }^{42}$. Table $5 \&$ and Figure 4 shows the samples collected at site 6, which displayed the highest Cd content at distance $0-5 \mathrm{~m}$ from road $(2.90 \pm 0.20 \mathrm{mg} / \mathrm{kg})$.

Table 5. Cadmium $(\mathrm{mg} / \mathrm{kg})$ in vegetable leaves of selected sites

\begin{tabular}{clccc}
\hline \multirow{2}{*}{ Site } & \multirow{2}{*}{ Vegetable } & \multicolumn{3}{c}{ Distance from road $(\mathrm{m})$} \\
\cline { 3 - 5 } & & $0-5 \mathrm{~m}$ & $5-10 \mathrm{~m}$ & $10-15 \mathrm{~m}$ \\
\hline 1 & Cauliflower & $1.20 \pm 0.10(1.10-1.30)$ & $0.60 \pm 0.10(0.50-0.70)$ & $0.00 \pm 0.00(0.00-0.00)$ \\
2 & Cabbage & $0.30 \pm 0.00(0.30-0.30)$ & $0.27 \pm 0.05(0.20-0.30)$ & $0.00 \pm 0.00(0.00-0.00)$ \\
3 & Cauliflower & $1.20 \pm 0.10(1.10-1.30)$ & $0.20 \pm 0.10(0.10-0.30)$ & $0.10 \pm 0.000 .10-0.10)$ \\
4 & Brinjal & $1.00 \pm 0.10(0.90-1.10)$ & $0.80 \pm 0.00(0.80-0.80)$ & $0.00 \pm 0.05(0.30-0.40)$ \\
5 & Brinjal & $1.30 \pm 0.05(1.00-1.10)$ & $0.70 \pm .0 .00(0.70-0.70)$ & $0.77 \pm 0.11(0.70-0.90)$ \\
6 & Radish & $2.90 \pm 0.20(2.70-3.10)$ & $2.30 \pm 0.28(1.70-2.20)$ & $1.83 \pm 0.20(1.60-2.00)$ \\
7 & Spinach & $0.50 \pm 0.00(0.50-0.50)$ & $0.23 \pm 0.05(0.20-0.30)$ & $0.00 \pm 0.00(0.00-0.00)$ \\
8 & Spinach & $0.90 \pm 0.10(0.80-1.00)$ & $0.63 \pm 0.05(0.60-0.70)$ & $0.53 \pm 0.05(0.50-0.60)$ \\
9 & Okra & $0.53 \pm 0.05(0.50-0.60)$ & $0.10 \pm 0.00(0.10-0.10)$ & $0.00 \pm 0.00(0.00-0.00)$ \\
10 & Radish & $1.63 \pm 0.11(1.50-1.70)$ & $0.00 \pm 0.00(0.00-0.00)$ & $0.00 \pm 0.00(0.00-0.00)$ \\
\hline
\end{tabular}

Mean $\pm S D($ Range $)$

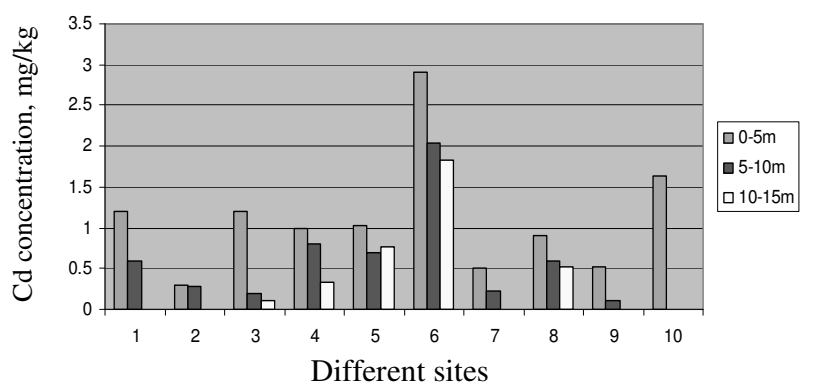

Figure 4. $\mathrm{Cd}(\mathrm{mg} / \mathrm{kg})$ in roadside vegetable leaves 
It is decreased to about $70 \%(2.03 \pm 0.28 \mathrm{mg} / \mathrm{kg})$ at distance $5-10 \mathrm{~m} \mathrm{\&} \mathrm{to} \mathrm{about} 63 \%$ $(1.83 \pm 0.20 \mathrm{mg} / \mathrm{kg})$. The lowest $\mathrm{Cd}$ concentration in cabbage leaves at $0-5 \mathrm{~m}$ distance from road was found; $0.30 \pm 0.00 \mathrm{mg} / \mathrm{kg}$ (site2) which is decreased to $0.27 \pm 0.58 \mathrm{mg} / \mathrm{kg}$ (at $5-10 \mathrm{~m}$ ) \& $0.00 \pm 0.00 \mathrm{mg} / \mathrm{kg}$ (at $10-15 \mathrm{~m}$ ). Simple correlation analysis revealed negative correlations between $\mathrm{Cd}$ concentration and distance from road, these were $\mathrm{r}=-0.75, \mathrm{p}<0.05$ (site5) to $\mathrm{r}=-0.99, \mathrm{p}<0.01$ (site7) except that of site $1 ; \mathrm{r}=-1.00, \mathrm{p}=\mathrm{ERR}$. The mean values of $\mathrm{Cd}$ content from all the vegetables sampled at different distances away from the highway were significantly different $(\mathrm{p}<0.01)$. The $\mathrm{Cd}$ concentration in all the vegetable samples were within the Indian (Prevention of food Adulteration act (PFA) permissible limit of $1.5 \mathrm{mg} / \mathrm{kg}$ except the sample of site $6(2.90 \pm 0.20 \mathrm{mg} / \mathrm{kg})$ and of site $10(1.63 \pm 0.11 \mathrm{mg} / \mathrm{kg})$. But all the samples accepted the much more stringent $(0.2 \mathrm{mg} / \mathrm{kg})$.

Inter-elemental relationships provide interesting information related to heavy metal sources and pathways. Pearson's correlation coefficients of heavy metal elements in soil and vegetable samples are presented in Table 6 and Table 7 respectively. Table 6 shows that $P b$ and $\mathrm{Cd}$ in soils are significantly positively correlated, suggesting a common origin. As the sampling areas have no industry, we may assume that the heavy metals analyzed derive mostly from motor traffic on the motorway from site 1 to the site 10 .

Table 6. Correlation matrix of soil $\mathrm{Pb}$ and $\mathrm{Cd}$

\begin{tabular}{ccc}
\hline Parameter & $\mathrm{Pb}$ & $\mathrm{Cd}$ \\
\hline $\mathrm{Pb}$ & 1 & $0.83(\mathrm{p}<0.01)$ \\
$\mathrm{Cd}$ & & 1 \\
\hline
\end{tabular}

Table 7. Correlation matrix of vegetables $\mathrm{Pb}$ and $\mathrm{Cd}$

\begin{tabular}{ccc}
\hline Parameter & $\mathrm{Pb}$ & $\mathrm{Cd}$ \\
\hline $\mathrm{Pb}$ & 1 & $-0.06(\mathrm{p}>0.05)$ \\
$\mathrm{Cd}$ & & 1 \\
\hline
\end{tabular}

In case of plant samples, correlation calculations between $\mathrm{Pb}$ and $\mathrm{Cd}$ gave non significant correlation coefficient. This may indicate that heavy metal pollution in roadside vegetable leaves may be due to other sources in addition to vehicular exhaust.

\section{Conclusion}

From the previous discussion, the following conclusions may be drawn:

1. The levels of heavy metals $(\mathrm{Pb} \& \mathrm{Cd}$ ) contamination in both soils and vegetables, decreased to background levels with distance on either side of the highway. The decrease of elemental concentrations with distance from highway would indicate aerial deposition of metal particulates in road side environment from extraneous sources and not a function of soil type. In Agra motor vehicles that burn leaded gasoline are mostly responsible for the build up of $\mathrm{Pb} \& \mathrm{Cd}$ in soil and vegetables along the highway through the emissions of particulates and wearing of tires. This conclusion agrees with that of Rodriguez- Flores and Rodriguez - Castellon (1982), who reported that the $\mathrm{Cd}$ and $\mathrm{Pb}$ levels in soil and vegetables decreased with increasing distance from the road ${ }^{44}$.

2. The concentrations of $\mathrm{Pb}$, especially in soil, exhibited a larger variation with distance from the road than those of $\mathrm{Cd}$. This may be explained by the relatively higher background values of $\mathrm{Cd}$ in the samples.

3. The roadside environment had a significantly high content of heavy metals $(\mathrm{Pb} \& \mathrm{Cd})$, especially $\mathrm{Pb}$ and the mean values of both these metals in soil and vegetables were significantly different at away from the highway $(\mathrm{p}<0.01)$. 
4. In terms of environment hazards and polluted city environment, it is suggested that the study on heavy metal contamination in soils and in several crops, especially those grown along the main road, should be conducted.

\section{Acknowledgment}

The authors are extremely grateful to Dr Ashok Kumar, Head of Department (Department of Chemistry), St John's Collage, Agra for rendering his support and help for the completion of this work.

\section{References}

1 Onianwa P C and Adoghe J O, Environment International, 1997, 23, 873-877.

2 Moller A, Muller H W, Abdullah A, Abdelgawad G and Utermann J, Urban soil pollution in Damascus, 2005.

3 Dolan L M J, Van Bohemen H D, Whelan P, Akbar K F, O'Malley V, O'Leary G and Keizer P J, The Ecology of Transportation: Managing Mobility for the Environment Springer Netherlands., 2006, 275-331.

$4 \quad$ Tsadilas C D, J Plant Nut., 2000, 23(8), 1167-1178.

5 Parekh P P, Khwaja H A, Khan A R, Naqvi R R, Malik A, Khan K and Hussain G, Environ Monit Assess., 2002, 74(3), 255-262.

$6 \quad$ Duzgoren A N S, Sci Total Environ., 2007, 385(1-3), 182-195.

7 Day J P, Hart M and Robinson M S, Nature, 1975, 253, 343-345.

8 Quijano R F, Health Issues in Urban Agriculture. Paper Presented at The National Conferences on Urban Agriculture Systems in the Philippines, Quezon City, Philippines, 2001, 15-17, 15.

9 Cui Y J, Zhu Y G, Zhai R H, Chen D Y, Huang Y Z, Qiu Y and Liang J Z, Environ Int., 2004, 30(6), 785-791.

10 Wang X, Sato T, Xing B and Tao S, Sci Total Environ., 2005, 350(1-3), 28-37.

11 Zheng N, Wang Q and Zheng D, Sci Total Environ., 2007, 383(1-3), 81-89.

12 Wittig R, Plants as Biomonitors: Indicators for Heavy Metals in the Terrestrial Environments, VCH, Weinheim, 1993, pp.3-28.

13 Aksoy A and Ozturk M A, Sci Total Environment, 1997, 205, 145-150.

14 Warren R S and Birch P, Sci Total Environment, 1987, 59, 233-256.

15 Aksoy A, Autecology of Capsella bursa-pastoris (L.) Medic, Ph.D Thesis, University of Bradford, Bradford, 1996.

16 Amar Ujala, Agra dilemma (News item), 29, November 2005, pp-9.

17 Mathur H B, National Program on Recent Advances in Environmental Pollution, New Delhi Proceedings, 1992, 14-21.

18 National Ambient Air Quality Monitoring Series: NAQQMS/ 28/2006-2007. Urban air monitoring: A case study in Agra. CPCB; 2002-2006.

19 Motto H L, Danies R P, Chilko D M and Motto C K, Environmental Science and Quality, 1970, 4, 231-237.

20 ICRCL, Interdepartmental Committee on the redevelopment of contaminated land. Guidance on the assessment and redevelopment of contaminated land. Guidance Note. 59/83.Department of Environment, London, 1987.

21 Davies B E and Holmes P L, J Agric Sci Cambridge, 1972, 79, 479-484.

22 Wheeler G A and Rolfe G L, Environ Pollut., 1979, 18, 265-274.

23 Hafen M R and Brinkmann R, Environ Geochem Health, 1996, 18, 171-179.

24 Turer D and Maynard J B, Clean Technology and Environmental Policy, 2003, 4, 235-245. 
25 Faiz A, Weaver C S and Walsh M P, Air pollution from motor vehicles, standards and technologies for controlling emissions. World Bank, Washington, D.C, 1996.

26 Nriagu J O, Sci Total Environ, 1990, 92, 13-27.

27 Kaysi I, Mamassani H S, Arnount S and Kattan L, Transportation Research. Part D., 2000, 5, 403-418.

28 Giannouli M, de Haan P, Keller M, Samaras Z, J Cleaner Production., 2007, 15, 1169-1182.

29 Caselles J, Water Air Soil Pollut., 1998, 105, 593-602.

30 Fakayode S O and Olu-Owolabi B I, Environ Geology, 2002, 44, 150-152.

31 Li L Y, Water Air Soil Pollut., 2006, 170, 211-277.

32 European Commission (EC) European Commission, Office for Official publications of the European Communities, Luxembourg, Council Directive 66/278/EEC on the protection of environment and in particular of soil, when sewage sludge is used in agriculture, 1986.

33 Kabata-Pendias A and Pendias H (Eds.,) Trace Elements in Soils and Plants. CRC Press, London, 1984.

34 Elsokkary I H and Lag, Acta Agric Scand., 1978, 23, 262-268.

35 Davies B E, 'Lead', in: Alloway, B.J. (Ed.,) Heavy Metals in Soils, Johin Wiley \& Sons, New York, 1990, pp 177-196.

36 Nwosu J U, Harding A K and Linder G, Bull Environ Contam Toxicol., 1995, 54, 570-578.

37 Zimdahl R L, J Air Pollut Control Assoc., 1976, 26, 655-660.

38 Adriano D C, Trace Elements in the Terrestrial Environment, Springer-Verlag, Heidelberg, 1986, pp. 219-262.

39 Singh N, Yunus M, Srivastava K, Singh S N, Pandey V, Misra J and Ahmad K J, Environ Monit Assess., 1995, 34, 13-26.

40 Lagerwerff J V and Specht A W, Environ Sci Technol., 1970, 4(7), 583-586.

41 Hewitt C N and Rashed M, Proc Int Conf Chemicals in the Environment, Lisbon, 1988 .

42 Bhatia I, Choudhri G N, Int J Ecol Environ Sci., 1991, 17, 121-127.

43 Rodriguez-Flores and Rodriguez-Castellon, M. Raodriguez-Flores and E. RodriguezCastellon, Environ Pollut., (B) 1982, 4, 281-290. 


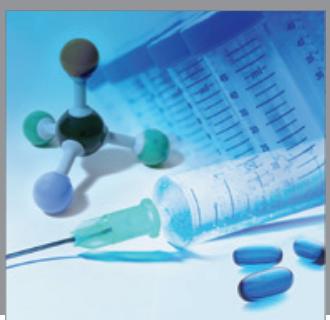

International Journal of

Medicinal Chemistry

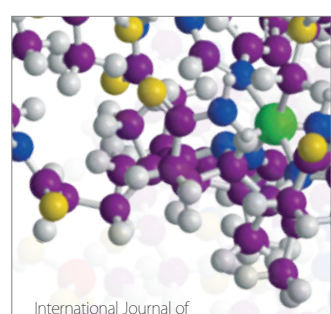

Carbohydrate Chemistry

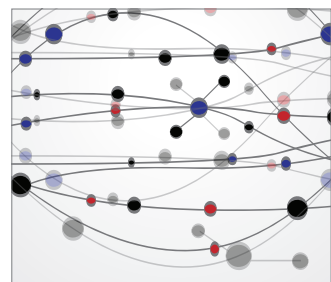

The Scientific World Journal
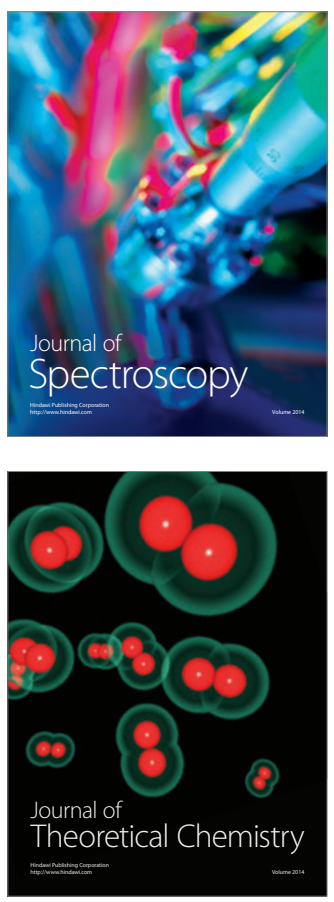
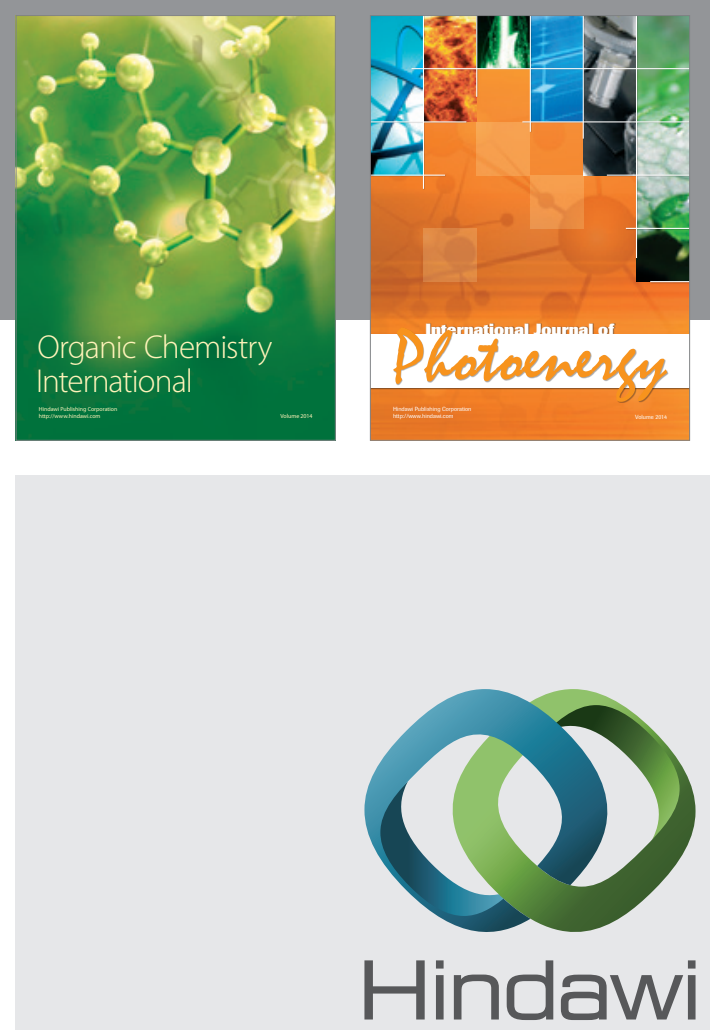

Submit your manuscripts at

http://www.hindawi.com
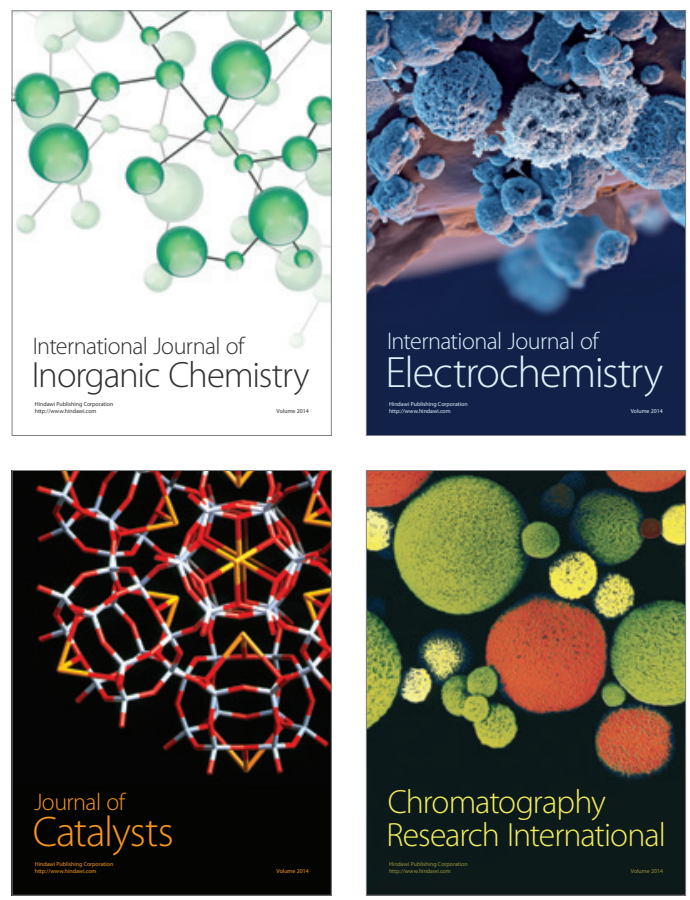
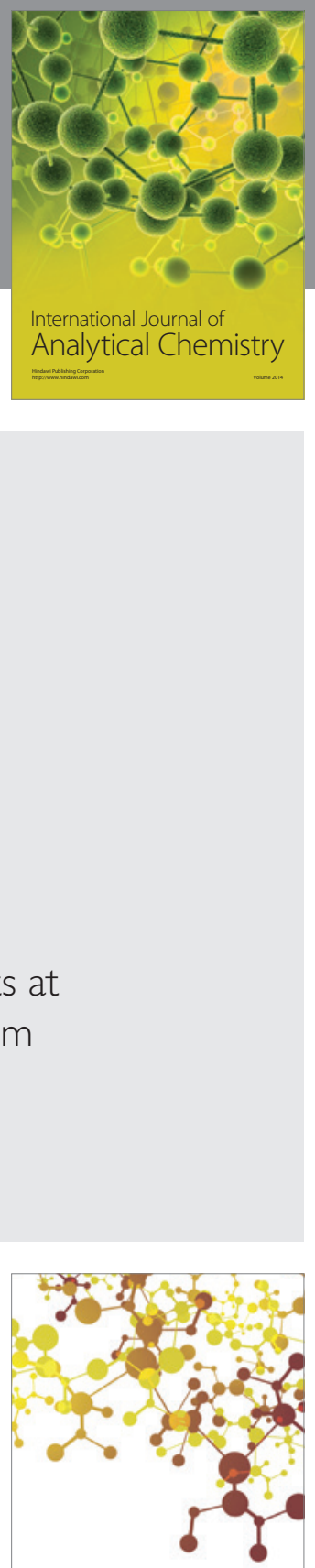

Journal of

Applied Chemistry
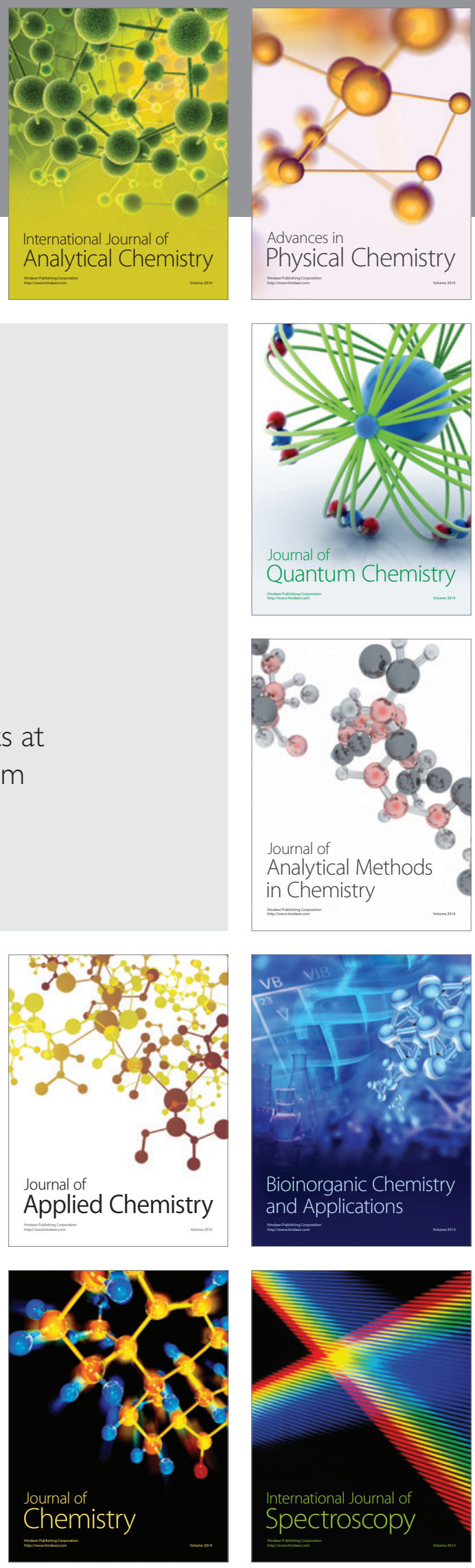